\author{
Joanna Dybiec-Gajer \\ Uniwersytet Pedagogiczny w Krakowie \\ joanna.dybiec-gajer@up.krakow.pl
}

\begin{abstract}
Implikacje utożsamiania przekładu z oryginałem. Polemika z interpretacją Złotej różdżki w książce Katarzyny Slany Groza w literaturze dziecięcej. Od Grimmów do Gaimana, Kraków 2016, 330 stron
\end{abstract}

DOl: http://dx.doi.org/10.12775/RP.2018.017

\begin{abstract}
Zarys treści: Złota różdżka (1858), której pierwowzorem jest niemiecki Struwwelpeter Heinricha Hoffmanna z 1845 roku, ma niekwestionowany status klasyki literatury dziecięcej. Mimo tej wysokiej pozycji w polisystemie twórczości dla dzieci poświęcono jej niewiele uwagi w polskiej literaturze przedmiotu. Dlatego z zainteresowaniem należy odnotować omówienie tego tekstu w monografii Groza w literaturze dziecięcej autorstwa Katarzyny Slany (Wydawnictwo Naukowe UP, 2016). Uważna lektura skłania jednak do krytycznego odniesienia się do zaproponowanego przez autorkę odczytania Złotej różdżki. Celem niniejszego artykułu jest pokazanie, jakie są implikacje merytoryczne upraszczającego traktowania przekładu - i to powstałego $w$ dziewiętnastowiecznej kulturze tłumaczeniowej, akceptującej dużą dozę wolności i kreatywności tłumacza piszącego dla dzieci - jako utworu tożsamego $z$ oryginałem.
\end{abstract}

Słowa kluczowe: przekład literatury dziecięcej, metodologia badań przekładoznawczych, metodologia komparatystyki, Złota różdżka, Struwwelpeter

Ysiążka Groza w literaturze dziecięcej. Od Grimmów do Gaimana Katarzyny SSlany z założenia nie jest pozycją przekładoznawczą. Łączy różne nurty metodologiczne współczesnej humanistyki i szeroko rozumianej krytyki literackiej, a jej celem jest zbadanie $\mathrm{w}$ tekstach literatury dziecięcej problematyki tytułowej grozy, rozumianej przede wszystkim jako „kategoria estetyczna” dla zjawisk, które „wzbudzają silne emocje, w tym przerażenie” (Slany 2016: 5). Obszerna lista omawianych utworów zawiera niekwestionowaną klasykę twórczości dla dzieci. Znajdziemy tu baśnie magiczne ze zbiorów braci Grimm i Charles’a Perraulta, baśnie Christiana Andersena, powieści E.T.A. Hoffmanna, Alicję w Krainie Czarów Lewisa Carolla oraz współczesne powieści grozy dla dzieci, m.in. autorstwa Roalda Dahla, Charlesa Ogdena czy Ne- 
ila Gaimana. Pełne zestawienie tekstów literackich w bibliografii (Slany 2016: 317-320) zawiera 70 pozycji dwudziestu sześciu autorów oraz dwadzieścia cztery baśnie. Wszystkie z nich, z wyjątkiem In the Night Kitchen M. Sendaka, to utwory przetłumaczone na język polski, głównie $\mathrm{z}$ angielskiego i niemieckiego. Całkowita nieobecność tekstów rodzimych jest wyborem świadomym i uzasadnionym, o czym świadczy następujący komentarz Autorki:

Trzeba [...] podkreślić, że brak w tym zestawieniu polskich powieści grozy dla dzieci, jako że w naszej literaturze dziecięcej zjawiska grozy, makabry i frenezji należały i nadal należą do rzadko podejmowanych tematów, szczególnie zaś tematów autotelicznych, jak zaprezentowane w tym opracowaniu. Wynika to zapewne z pokutującego od XIX wieku postulatu o użyteczności literatury dziecięcej, która ma spełniać funkcję dydaktyczną i moralizującą, oraz z rodzimego kontekstu historycznego, narzucającego określony zbiór motywów, postaci i wątków utylitarnych, w których funkcja ludyczno-ekspresywna nie pełni znaczeń pierwszoplanowych (Slany 2016: 15-16).

Wydawałoby się, że taka budowa korpusu, zawierającego prawie wyłącznie przekłady, w sposób nieunikniony predestynuje Badaczkę do uzupełnienia wykorzystanego instrumentarium o metodologie przekładoznawstwa. Tym bardziej, że jak sama powyżej sugeruje, obrazy grozy w literaturze dziecięcej wydają się być importem kulturowym. W związku z tym prześledzenie ich dróg i zakorzeniania się w polskim polisystemie literackim może być bardzo poznawczo interesujące. Autorka nie sięga jednak po prace z zakresu badań nad przekładem. W obszernej bibliografii opracowań naukowych między otwierającą listę Janiną Abramowską z pracami z tematologii i poetyki historycznej a zamykającym ją Slavojem Žižkiem z traktatem Welcome to the Desert of the Real znajdują się studia literackie, psychologiczne, pedagogiczne, etnograficzne, filozoficzne i psychoanalityczne, ale nie znalazłam żadnego przekładoznawczego. Przeanalizujmy zatem, jakie są implikacje pisania o tłumaczeniach bez wsłuchania się w głos tłumaczy i badaczy przekładu. Skupię się na zaproponowanej przez Autorkę interpretacji Złotej różdżki, pojawiającej się raczej peryferyjnie w polskich badaniach. Dobrą okazją ku temu jest przypadająca na 2018 rok 160-rocznica pierwszego polskiego wydania tej książki.

Rozpocznę od przedstawienia omawianego utworu w telegraficznym skrócie. Złota rószczka, bo tak pierwotnie zapisywano jej tytuł, to polska wersja zbioru wierszy Heinricha Hoffmanna znanego jako Der Struwwelpeter (pierwsze wydanie 1845), uznawanego za jedną z pierwszych nowoczesnych 
książek dla dzieci i prekursora komiksu. W kanonicznej formie książka zawiera 10 historyjek o dzieciach, które za nieposłuszne zachowanie spotyka straszna kara. Wyjątkiem w tym dydaktycznym katalogu jest ludyczna historia o groźnym myśliwym, która stanowi ilustracje „świata na wspak”. Podczas drzemki myśliwego następuje odwrócenie ról: zamiast pokotem słać zające znajduje się on niespodziewanie $\mathrm{w}$ roli ofiary mierzącego do niego $\mathrm{z}$ jego własnej strzelby zająca. Od początku publikacji zbiorek był kontrowersyjny, przyciągał czytelników o czym świadczy ogromna liczba wydań i tłumaczeń, aczkolwiek zbierał też cięgi krytycznych opinii. Złota różdżka, o której czytamy $W$ grozie... nie jest spolszczeniem niemieckiego oryginału, ale wolnym przekładem rosyjskiego z kolei tłumaczenia pt. Stiopka Rastriopka. Rasskazy dlia dietiej $(1849)^{1}$, nie zawierającym wspomnianej historii o myśliwym oraz okolicznościowego, bożonarodzeniowego wstępu. Nie wchodząc w szczegółową analizę przekładoznawczą, w tym wpływ tekstu pośredniczącego w języku rosyjskim, polską wersję tekstową w odniesieniu do niemieckiego pierwowzoru charakteryzuje:

- oddanie dynamizmu i humoru narracji, sprawne operowanie materią języka;

- ograniczenie ambiwalencji pierwowzoru i w związku z tym możliwości różnorakich odczytań;

- stosowanie amplifikacji - dopisywanie morałów oraz przerysowywanie elementów potęgujących strach;

- kompensacja dystansu emocjonalnego obecnego w tekście niemieckim.

Prześledźmy teraz zaproponowaną czytelnikowi interpretację Złotej różdżki, zamieszczoną w ostatnim rozdziale pt. „Dziecięca powieść grozy” (podrozdział „Mroczny fantazmat dzieciństwa”). Autorka przytacza obszerne fragmenty wierszy ze zbioru, przy czym pięć z sześciu wybranych przez nią przykładów znakomicie ilustruje wyszczególnione powyżej interwencyjne zabiegi tłumacza, co pokazuje, że Autorka swoje tezy o utworze Hoffmanna uzasadnia przede wszystkim kreatywnymi rozwinięciami tłumacza. W przykładach znajdziemy zatem dopisane w tłumaczeniu morały i uogólniające pouczenia „Tego nadto - krzyknął stary - nieposłusznym trzeba kary” („Czarne

${ }^{1}$ Niedawno ukazały się dwie nowe polskie edycje Struwwelpetera: Piotruś Rozczochraniec. Wesołe historyjki i zabawne rysunki (tł. Lech Konopiński, Edition Tintenfaß 2015) i Złota różdżka, czyli bajki dla niegrzecznych dzieci (wieloautorska adaptacja, Egmont Art 2017) oraz opracowanie krytyczne Złota różdżka - od książki dla dzieci po dreszczowiec raczej dla dorosłych (Dybiec-Gajer, Tertium 2017). 
dzieci”), „Bo kara Boża tam gdzie swawola” („Straszny przypadek z parasolem”) i najsławniejszy chyba cytat ze zbioru „Kto nie je zupy ten umrzeć musi” („Historia bardzo smutna o chłopcu, który nie chciał jeść zupy”). Warto podkreślić, że nie występują one ani u Hoffmanna, ani w Stiopce Rastriopce. W najbardziej rozpoznawalnym wierszu „O Juleczku, co miał zwyczaj ssać palec" w tłumaczeniu w stosunku do tekstu niemieckiego zwielokrotniona zostaje kara, bowiem milczący niemiecki krawiec w polskim tekście strofuje jeszcze pozbawionego już kciuków chłopca: „Tak z nieposłuszeństwa leczę”, a matka odmawia mu ciasteczek, „Bo kto mamy nie usłucha / temu dosyć bułka sucha".

Najbardziej radykalną zmianę odnajdziemy w „Pawełku wiercipięcie” (niem. „Zappel-Philipp”). Zakończenie wiersza opisuje gwałtowne zachowanie ojca, doprowadzonego do pasji przez huśtającego się na krzesełku syna, który strącił ze stołu obiad z zastawą i obrusem, a podsumowane jest druzgocącym dwuwierszem „I ukarał ojciec syna, / Aż trzeszczała dyscyplina”. Cały przytoczony przez Autorkę emocjonalny fragment zakończenia, składający się z dziesięciu wersów, jest autorską interpretacją tłumacza: zarówno tekst niemiecki, jak i jego rosyjski przekład nie wspominają ani nagłego zachowania ojca, ani wymierzania przez niego kary fizycznej. Piętnowane przez Slany „katorżnicze bicie” Pawełka (2016: 255) zawdzięczamy wyłącznie decyzji tłumacza. Co więcej, Hoffmannowski ojciec jest powściągliwy w swoich uwagach. Na wiercenie i huśtanie się na krześle syna reaguje tak, jak zaleca współczesna pedagogika: nie krytykuje chłopca i nie etykietuje, piętnując tylko jego zachowanie w konkretnym momencie: „Philipp, dass missfällt mir sehr” - dosłownie, 'Philippie, to bardzo mi się nie podoba'. Etykietują za to tłumacze. Pisząc o chłopcu "mały ty ladaco" tłumacz polski podąża drogą wytyczoną przez tekst rosyjski, gdzie również znajdziemy nieprzychylne dla bohatera dziecięcego określenie „злодей” ('złoczyńca').

Cytowane przez Autorkę przykłady są również o tyle znaczące, że pokazują wybrane przesunięcia semantyczne i estetyczne względem niemieckiego i rosyjskiego pierwowzoru, które następują w obrębie punktów krytycznych czy też dominanty translatorskiej utworu (por. Dybiec-Gajer 2012 i 2017), czyli szczególnie istotnych sensotwórczych elementów tekstu. Moralizatorska rama, w jaką Struwwelpeter zostaje wpisany przez przekład, stoi w sprzeczności z programowymi założeniami Hoffmanna. W oryginale konsekwentnie brak zwerbalizowanych morałów czy nauczek, narrator oschle relacjonuje, ale nie poucza i nie ocenia. Autor podkreślał bowiem, że dla dzieci niezrozumiałe i bezużyteczne są abstrakcyjne pouczenia, a przemawia do nich konkret otaczającego je świata. 
Na swoje czasy Struwwelpeter był utworem nowoczesnym, choć czerpał z wcześniejszych tradycji. O jego atrakcyjności i nowatorskości - oprócz zintegrowania tekstu i ilustracji w autorską książkę obrazkową - przesądza też traktowanie postaci dziecięcych. Rodzice, tak jak i inni dorośli, są raczej bohaterami dalszego planu, ustępując pierwszoplanowego miejsca wyrazistym i nakreślonym z rozmachem bohaterom dziecięcym. Co więcej, rodzice i opiekunowie nie występują w roli instancji karzącej, tym bardziej nie wymierzają kar fizycznych (por. Sauer 2015a). Należy też koniecznie podkreślić, że kara wynika z natury rzeczy, a jeśli zostaje wymierzona, to przez osoby trzecie (krawiec, Niklas²). Dzieci pozostawione są w sytuacjach, w których najczęściej same dokonują wyboru i same ponoszą konsekwencje swoich czynów. Są same i wydaje się, że czasem i samotne, nie ma przy nich troskliwych dorosłych opiekunów i bliskich towarzyszy - nie bez przyczyny Stahl pisze o „egzystencjalnym osamotnieniu” bohatera dziecięcego w Struwwelpeterze (Stahl 2006: 218).

W związku z tym trudno znaleźć merytoryczne argumenty na uzasadnienie takiego odczytania roli dorosłych:

Dorośli (najczęściej opiekun dziecka, ale także demoniczna postać z zewnątrz: olbrzym, mag, szalony krawiec i inni) jawią się w zbiorze Hoffmanna jako „okrutni opiekunowie”, którzy pod pozorami nauki dobrych manier i grzeczności z lubieżną satysfakcją torturują dziecko, zadają mu ból lub doprowadzają je do śmierci. Rodzice i wychowawcy spełniają tu znamienną funkcję egzekutorów superporządku, występując w roli krwawych katów, sadystów, psychopatów, pragnących ujarzmić „rozedrganą" i wywrotową naturę dziecięcą poprzez system tortur i egzekucji (Slany 2016: 254).

Zwróćmy również uwagę, że wymienione przez autorkę „egzekucje”, z wyjątkiem działalności przeskalowanego a przez to odrealnionego krawca, to daleka interpretacja, nie znajdująca potwierdzenia nawet $\mathrm{w}$ tekście polskiego przekładu. Wewnętrznie niespójna jest również argumentacja autorska o karzącej roli rodziców, ponieważ wcześniej czytamy, że „[s]zczególną uwagę przykuwa [...] sytuacja wyolbrzymionej kary (będącej szyderczym wy-

${ }^{2}$ W oryginale występuje postać Niklasa (Mikołaja), który w tradycji niemieckiej, tak jak i w polskiej, nie tylko obdarowuje grzeczne dzieci prezentami, ale także każe. W przekładzie rosyjskim, ze względów na cenzurę, zrezygnowano z postaci Mikołaja, jako że mogła ona stanowić nawiązanie do panującego cara o tym samym imieniu i zastąpiono go starcem-czarodziejem. Wyjaśnia to pojawienie się czarodzieja również w tekście polskim. 
naturzeniem kary naturalnej)". Popatrzmy zatem na wymieniony przez Autorkę katalog kar, jakoby stosowanych przez dorosłych „katów” (Slany 2016: 254-255):

- „porwanie w przestworza” („Straszny przypadek z parasolem”) $\mathrm{w}$ wierszu nie występują bohaterowie dorośli, a chłopiec zostaje uniesiony przez wiatr. Nota bene ilustracyjna oprawa B. Szymanowskiego do wydań warszawskich Złotej różdżki - wbrew tekstowi polskiemu i niemieckiemu otwartemu zakończeniu - domyka finał historii, umieszczając zagubionego chłopca na księżycu;

- „podtapianie” („Jędruś Gap”) - tytułowy bohater sam wpada do wody, a z opresji ratują go właśnie znajdujący się w pobliżu dorośli. Żywotność Hoffmannowskiego motywu w epoce dzieci jako cyfrowych tubylców pokazują współczesne niemieckie transmedialne realizacje (memy) i pastisze, w których Hans Guck-in-die-Luft (w adaptacji Egmont Art - Jacek Wniebogapek) zamiast spoglądać w przestworza nie może oderwać oczu od ekranu komórki (por. Struwwelpost 2016: 45);

- „przemiana w monstrum” („Czarne dzieci”) - u przedrzeźniających chłopców nie następuje żadna przemiana, ani „przepoczwarzenie” (Slany 2016: 256), zostają tylko skąpani w atramencie. Hoffmannowscy bohaterowie - z wyjątkiem Konrada - nie zostają prawdziwie poskromieni. Doznają przykrych, a nawet tragicznych konsekwencji swoich czynów, ale nie wyrażają skruchy i żalu, nie okazują też chęci poprawy. Tak jak w innych utworach o niegrzecznych dzieciach tego okresu i późniejszych nie widzimy ich przemiany w ułożone i posłuszne dzieci. Naśmiewający się z czarnoskórego chłopcy przez zanurzenie $\mathrm{w}$ atramencie doznają upokorzenia, ale narrator nie dopowiada, czy stali się przez to mądrzejsi i bardziej tolerancyjni. Brak przemiany i poprawy bohaterów oraz karcących komentarzy narratora to jeden z głównych powodów krytyki wysuwanej pod adresem Struwwelpetera. Powoduje on bowiem, że pouczający i dydaktyczny przekaz zbioru wydaje się być pozorny (por. Wesseling 2004).

Metodologiczne uchybienia polegające na utożsamianiu przekładów z tekstami oryginałów nie są niestety odosobnione w polskich badaniach nad światową klasyką literatury dziecięcej. Młodzi badacze, i nie tylko, traktują Złotą różḋ̇kę często jako utwór oczywisty (por. Dybiec-Gajer 2017: 137), flagowy przykład XIX-wiecznej czarnej pedagogiki, nie sięgając ani po niemiecki pierwowzór, ani tym bardziej po rosyjski tekst wyjściowy. Ponadto bardzo wstrzemięźliwie korzystają z obszernej literatury przedmiotu. Zwróćmy uwagę, że uaktualniona bibliografia prac krytycznych poświęconych fenomenowi 
Struwwelpetera i jego autora zawiera ponad 800 tytułów (Sauer 2015b), przy czym w Grozie w literaturze dziecięcej znajdują się odwołania do zaledwie dwóch prac i to nie najważniejszych. Brak odniesienia do przełomowych prac Janusza Dunina, który zrekonstruował wiele faktów $\mathrm{z}$ historii tej książki, opracował też reedycję petersburskiego wydania (2003a), w ten sposób chroniąc Złotą różdżkę od zapomnienia. Obszerność literatury przedmiotu nie wynika bynajmniej tylko z obszerności materiału badawczego (jeszcze za życia Hoffmanna ukazało się setne wydanie Struwwelpetera, rozliczne są przekłady, trawestacje i naśladownictwa). Zainteresowanie generuje sam utwór, w którym ścierają się różne, często paradoksalne wizje, doskonale wychwycone i wypunktowane przez Stahla (2006). Powierzchowne i sztampowe odczytanie jednego tylko przekładu jako oryginału, wspomagane odniesieniami do krytykowanych prac psychoanalitycznych (por. Sauer 2015) powoduje, że w konsekwencji utwór w dużym stopniu ambiwalentny, na swoje czasy nowatorski, pozwalający na nowe odczytania i interpretacje, dalej żywy w obiegu kultury wysokiej i popularnej został w Grozie w literaturze dziecięcej jednoznacznie zaszufladkowany jako kuriozalny antyprzykład literatury dla dzieci.

Podobne wnioski o niedostatkach metodologicznych niektórych prac naukowych oraz recenzji poświęconych tekstom literatury dziecięcej formułują także inni badacze. Omawiając recepcję krytyczną Kubusia Puchatka i Fredzi Phi-Phi, Szymanowska zauważa: „[t]on recenzji pokazuje [...] swego rodzaju tradycyjne naiwne przekonanie o jedyności przekładu i jego identyczności z oryginałem, które to przekonanie podważa istnienie serii translatorskich" (2014: 201). Z kolei badaczka recepcji i przekładu baśni braci Grimm, a także ich tłumaczka, Eliza Pieciul-Karmińska (2016: 78) pisze:

często sami naukowcy zajmujący się w swej pracy baśniami Grimmów, niebędący germanistami i przez to niemający dostępu do tekstu oryginalnego, zapominają, że obcują z przekładami, i często na podstawie swobodnych lub przypadkowo dobranych przekładów formułują wnioski, które nie mają wiele wspólnego z treścią czy przesłaniem oryginału.

W kontekście baśni braci Grimm i H. Andersena warto przypomnieć tezę Caya Dollerupa o umiędzynarodowieniu baśni, w którym kluczową rolę odgrywają właśnie tłumaczenia. W Tales and Translation (1999) duński badacz pokazuje, jak baśnie te zakorzenione są bardziej w kulturze przekładu niż w poszczególnych, narodowych kulturach literackich. Zwraca również uwagę, jak w zglobalizowanym i zmediatyzowanym świecie rośnie rola ilustratorów i wydawców, a maleje rola indywidualnych tłumaczy w opowiada- 
niu baśni. W Grozie... omówienie baśni, tak jak i innych pozycji klasyki dla dzieci, zajmuje znaczące miejsce, jednak ocenę interpretacji oraz trafności wyciągniętych przez Autorkę wniosków pozostawiam badaczom, którzy tymi tekstami zajmują się w swoich pracach.

Omawiana książka z pewnością sięga po ciekawe i mało przebadane obszary literatury dziecięcej i zasługuje na uwagę. Badaczom przekładu i nie tylko przyjemność z lektury mogą jednak zepsuć niedociągnięcia warsztatowe Autorki, a także nierzadka u młodych naukowców skłonność do nieuzasadnionych sądów i forsowania radykalnych tez jak ta, że „nie powinny powstawać utwory dla dzieci wolne od klimatu grozy" (Slany 2016: 12). Jak pokazuje Groza w literaturze dziecięcej, można pisać o przekładzie bez wsłuchania się w głos tłumacza i przekładoznawcy. Zaskakuje jednak, że w kulturze autorefleksyjności nad działaniem badacza można w ogóle nie zauważyć czy zapomnieć, że takie głosy istnieją. W narracji brak świadomości, że przekład jest odrębnym tworem literackim i kulturowym, który chociaż związany $\mathrm{z}$ oryginałem nie może być $\mathrm{z}$ nim utożsamiany. Można pisać ciekawie, barwnie, inspirująco i z pasją, jak to czyni Autorka, aczkolwiek nie do końca merytorycznie. Praca podejmuje interesujący i aktualny temat, ale z perspektywy badań nad przekładem rozczarowuje. Autorka kończy swoje rozważania następującym cytatem: „Fałszowanie rzeczywistości wiedzie [...], jak twierdził Bruno Bettelheim, do degradacji osobowości dziecka oraz do nieumiejętności zmierzenia się z własną »ciemnością "” (Slany 2016: 297). Wyciąganie wniosków o funkcjonowaniu kategorii grozy w tekstach dla dzieci będących przekładami bez uwzględnienia lub przynajmniej zasugerowania filtrów nałożonych przez tłumaczy, wydawców i współtworzoną przez nich kulturę tłumaczeniową wydaje się takim właśnie fałszowaniem rzeczywistości.

Wymienione w polemice uwagi krytyczne nie mają na celu zdyskredytowania wartości książki i wysiłku Autorki, która podeszła do swojego zadania z dużą pasją, zaangażowaniem i oryginalnością, co podkreślili już słusznie recenzenci pracy, ale ulepszeniu warsztatu metodologicznego młodych badaczy, którzy obierają teksty przekładów za przedmiot swoich rozważań i dociekań naukowych.

\section{Teksty źródłowe}

Hoffmann, H., 1922, Złota różdżka - Staś straszydło. Czytajcie dzieci, uczcie się, jak to niegrzecznym bywa źle, ilustracje Bogdan Nowakowski, Warszawa. 
Hoffmann, H., 1849, Stiopka Rastriopka, Rasskazy dla dietiej, St Petersburg. Hoffmann, H., 1929, Der Struwwelpeter oder lustige Geschichten und drollige Bilder für Kinder von 3-6 Jahren von Dr. Heinrich Hoffmann. 585. Auflage, Frankfurt am Main.

Hoffmann, H., 2015, Piotruś Rozczochraniec. Wesołe historyjki i zabawne rysunki. Wydanie dwujęzyczne, przekład Lech Konopiński, Neckarsteinach.

Hoffman, H., 2017, Złota różḋ̇ka, czyli bajki dla niegrzecznych dzieci, adaptacja Anna Bańkowska, Karolina Iwaszkiewicz, Zuzanna Naczyńska, Adam Pluszka, Michał Rusinek, Marcin Wróbel, ilustracje Justyna Sokołowska, Warszawa.

\section{Literatura sekundarna}

Dunin, J., 2003a, Złota Rószczka. Reedycja petersburskiego wydania z roku 1883 /Heinrich Hoffmann. Struwwelpeter, Stepka-Rastrepka czyli Złota różdżka. $Z$ dziejów kariery jednej książki/, Łódź.

Dunin, J., 2003b, „»Struwwelpeter«, czyli »Złota różdżka«: z dziejów kariery jednej książki”, [w:] Acta Universitatis Wratislaviensis. Literatura i Kultura Popularna, t. 11, s. 133-144.

Dybiec-Gajer, J., 2017, Złota różdżka. Od książki dla dzieci po dreszczowiec raczej dla dorostych, Kraków.

Dybiec-Gajer, J., 2013, Zmierzyć przekład? Z metodologii oceniania $w$ dydaktyce przekładu pisemnego, Kraków.

Dybiec-Gajer, J. 2012, „The challenge of simplicity: Le Petit Prince in Polish and English translation from the perspective of critical point analysis", [w:] Le Petit Prince et les amis au pays des traductions: études dédiées a Urszula Dąmbska-Prokop, J. Górnikiewicz, I. Piechnik, M. Świątkowska (red.), Kraków, s. 112-127.

Pieciul-Karmińska, E., 2016, „O konieczności polskiego przekładu pierwszego wydania Baśni dla dzieci i dla domu braci Grimm z lat 1812 i 1815”, [w:] Rocznik Przekładoznawczy, t. 11, s. 77-92.

Sauer, W., 2015a, „Hoffmann, Heinrich: Struwwelpeter”, http://www.kinderundjugendmedien.de/index.php/werke/1344-hoffmann-heinrich-struwwelpeter (dostęp: 20 listopada 2016 r.)

Sauer, W., 2015b, Der Struwwelpeter und sein Schöpfer Dr. Heinrich Hoffmann. Bibliographie der Sekundärliteratur, Neckarsteinach.

Stahl, J. D., 2006, „Mark Twain's Slovenly Peter in the Context of Twain and German Culture", [w:] The Translation of Children's Literature: A Reader, G. Lathey (red), Clevedon, s. 211-224. 
Szymańska, I., 2014, „Przekłady polemiczne w literaturze dziecięcej”, [w:] Rocznik Przekładoznawczy, t. 9, s. 193-208.

Wesseling, E., 2004, „Visual Narrative in the Picture Book: Heinrich Hoffmann's Der Struwwelpeter", Children's Literature in Education, t. 35, z. 4, s. 319-345.

Implications of identifying translation with the original. A critical dispute with the interpretation of Złota różdżka in Groza w literaturze dziecięcej. Od Grimmów do Gaimana [Horror in children's literature. From the Grimms to Gaiman] by Katarzyna Slany, Kraków 2016, 330 pp.

\section{Summary}

The paper reviews the book Groza w literaturze dziecięcej. Od Grimmów do Gaimana [Horror in children's literature. From the Grimms to Gaiman] by Katarzyna Slany (Kraków 2016, 330 s.). Taking a large sample of texts for children, the author of the book under consideration discusses the representations of horror understood as an aesthetic category. All of the texts but one selected for analysis are translations into Polish, a fact which the author disregards, presenting her arguments as if the translations were identical with their source texts. The review explores the implications of such a methodological shortcoming, focusing on the author's discussion of Złota różdżka, an indirect rewriting of H. Hoffmann's classic Der Struwwelpeter (1845) based on Russian Stiopka Rastriopka (1849).

Keywords: children's literature in translation, Translation Studies research, comparative studies methodology, Złota różdżka, Struwwelpeter

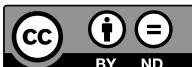

